\title{
IDENTIFYING Higher ORDER THINKING ACTIVATION IN ENGLISH TEXTBOOK MANDATED IN INDONESIAN SENIOR High SCHOOL
}

\author{
Anton Muzaeni Syukur, Misdi \\ English Education Department, University of Swadaya Gunung Jati
}

antonmuzaeny@gmail.com, misdi@gmail.com

\begin{abstract}
This paper aims at investigating factual phenomenon of higher order thinking as it reflected in the reading activities of Bahasa Inggris SMA/MA XI. Using theory of Bloom's (2001) taxonomy, this study used the content analysis method to identify reading features specifically for their essay questions and exercises and tasks of the English textbook. The data of essay reading questions were collected by using coding checklist. Three categories of higher order thinking (analyze, evaluate, and create) were discovered while the distribution of the higher order thinking level is higher than the lower order thinking level. The finding reveal higher order thinking activation and activities in the reading exercises and tasks was unequal, especially the create skills which pursued lower distribution, e.g.not provide treatment properly of the higher order thinking than the analyze skill and the evaluate skill. This puts emphasis on the evaluate skills.
\end{abstract}

Keywords: Higher Order Thinking, Reading Exercise, English Textbook

\section{INTRODUCTION}

In English language teaching process, English textbooks performs a substantial role in EFL classroom because it provides beneficial guidance and covers the materials that teachers need to deliver. As one language activities, reading is a crucial part that stimulates higher order thinking skills because the students need to analyze and synthesize what they have read. An effective English textbook must have relevant reading perhaps followed by exercises and questions. Besides, those exercises assist students to understand the teaching material and to know their ability in reading as the basic skill of the language. By giving the questions, reading exercises should involve higher order thinking skills due to the involvement of five scientific processes on 2013 curricula.

Krathwohl (2002) offered three levels of higher order thinking in Bloom's revised taxonomy; namely analyze, evaluation and create. Farrel (2002) stated that most of language textbooks for example reading textbook gives exercises such as predicting, inference, checking prior knowledge, and guess the content of the text. Seif (2012) examined the higher order thinking activation in reading sections of English textbooks distributed in Palestine. The findings reveal analysis skill 51.92\%, synthesis skill $41.35 \%$ and evaluation skill got $6.73 \%$. The reading activates fairly students higher order thinking.

Another study was also conducted in 2016. Lubis (2016) reported his high order thinking analy sis from senior high school English textbook. The report shows $12.9 \%$ for analyze skill, $2.6 \%$ for evaluate skill, and $1.2 \%$ for create skill while lower order thinking skills got $83.2 \%$. To this, the higher order thinking still exists in English textbook even if it has the lower number of distribution than the lower order thinking. Recent study revealed revealed that $95.6 \%$ belongs to lower order thinking skillremember $(55.7 \%)$, understand $(36.8 \%)$, apply $(3.1 \%)$, whereas, $4.4 \%$ belongs to higher order thinking skill-analyze (2.2\%), evaluate (2.2\%), and create $(0 \%)$ (Sari, 2017). The reading exercises in English textbook activate students higher order thinking although it has the lower number than the lower order thinking. The rare analysis in the contexts of Indonesian schooling English textbook has driven this study to address critical thinking activation as reflected in the reading activities. Thus, the current research aims at identifying critical thinking activation as it indicated in the reading activities which potentially promote critical thinking in their completion.

\section{MATERIALS AND METHOD}

A content analysis (Ary, et al., 2010) was employed as the technique of data analysis in this current research. The data were collected following Bashir, et al'. (2014) Bahasa Inggris SMA/MA XI. The book was published by National Ministry of Education and Culture. In addition, descriptive statistics was employed in presenting the results of data analysis to show the higher order thinking features of the English textbook. In the last stage, the descriptive statistics results were then critically interpreted qualitatively. 


\section{RESULTS AND DISCUSSION}

\subsection{ChAPTERS AND READING TEXTS}

The textbook Bahasa Inggris SMA/MA XI purveys many exercises for students to study. Overall, the book serves all language skills such as activities of speaking, listening, reading, and writing with their language components. These are present in the whole exercises and tasks for the students. However, it is the reading exercises and tasks which are the focus of the study. Eight reading texts were found to be explored and investigated texts-folklore, opinion article (discussion text), speech (argumentative text), a play, formal invitation, short story, personal letter, a skit (a short comical/funny drama) as shown in the following table.

\begin{tabular}{lllll|}
\hline Chapter & Theme & $\begin{array}{l}\text { Number of } \\
\text { Exercises }\end{array}$ & $\begin{array}{l}\text { Reading } \\
\text { Exercises }\end{array}$ & $\begin{array}{l}\text { Essay Reading } \\
\text { Exercise }\end{array}$ \\
\hline 1 & $\begin{array}{l}\text { Can greed ever be } \\
\text { satisfied? }\end{array}$ & 15 & 10 & $4(1,2,3, \& 6)$ \\
2 & $\begin{array}{l}\text { Bullying: a cancer that } \\
\text { must be eradicated }\end{array}$ & 14 & 10 & $3(1,2, \& 3)$ \\
3 & Hopes and dreams! & 13 & 7 & $3(1,2, \& 3)$ \\
4 & $\begin{array}{l}\text { Vanity, what is thy } \\
\text { price? }\end{array}$ & 11 & 7 & $3(1,2, \& 3)$ \\
5 & Benefit of doubt & 12 & 7 & $3(1,2, \& 3)$ \\
\hline TotalExercises & 65 & 38 & 16 & \\
\hline
\end{tabular}

\section{Table 1. Essay Reading Exercise distribution}

65 exercises in the textbook Bahasa Inggris SMA/MA XI practicing and promoting all language skills as well their components while 38 exercises practice the reading skill. Nevertheless, 16 out of 38 - amounts of the reading exercises in the textbook - the essay reading exercises. Meanwhile, the rests are not only the other types of reading exercises but also essay reading exercise like responding, reading aloud, multiple-choice, editing, short-answer, gap-filling, fill in the blank, complete the colu mn, cloze, labeling, and matching. From the textbook, the distribution of the essay reading exercises is supposed to provide more attention again, because it has lower distribution compared to the other reading exercises types. Test types of the reading are presented in the following table.

\begin{tabular}{|c|c|c|c|c|c|c|}
\hline \multirow{2}{*}{ Exercise types } & \multicolumn{5}{|c|}{ Chapter and numbers of exercises } & \multirow{2}{*}{ Total } \\
\hline & $\mathbf{1}$ & 2 & $\mathbf{3}$ & 4 & 5 & \\
\hline Essay & $1,2,3,8$ & $1,2,3$ & $1,2,3$ & $1,2,3$ & $1,2,3$ & 16 \\
\hline Responding & - & - & 6 & 6 & - & 2 \\
\hline Reading Aloud & 4 & 4 & 4 & 4 & 4 & 5 \\
\hline Multiple-Choice & 5 & - & - & - & - & 1 \\
\hline Editing Task & 6 & - & 5 & 6 & 6 & 4 \\
\hline Short-Answer & 7 & 8 & - & - & - & 2 \\
\hline Gap-Filling & 9 & - & - & - & - & 1 \\
\hline Fill in the Blank & 10 & 6,10 & 7 & 5 & 7 & 6 \\
\hline
\end{tabular}




\begin{tabular}{llcllll}
\hline \multirow{2}{*}{ Exercise types } & \multicolumn{7}{c}{ Chapter and numbers of exercises } & Total \\
\cline { 2 - 6 } & $\mathbf{1}$ & $\mathbf{2}$ & $\mathbf{3}$ & $\mathbf{4}$ & $\mathbf{5}$ & \\
\hline Complete the Column & - & 5,7 & - & - & - & 2 \\
Labeling & - & 9 & - & - & - & 1 \\
Matching Task & - & - & - & - & 5 & 1 \\
Cloze Task & 15 & 14 & 13 & 11 & 12 & 5 \\
\hline Totalexercises/tasks & 11 & 11 & 8 & 8 & 8 & 46 \\
\hline
\end{tabular}

Table 2. Exercises and tasks types in reading

12 types of reading exercises, such as essay question, responding question, reading aloud, multiple-choice question, editing, short-answer question, gap-filling, fill in the blank, complete the column, labeling, matching, and cloze task. Either of the highest distribution (see the table) - clearly the essay question out of two more another test types, like short-answer and fill in the blank, those are, by acquiring 16 exercises out of 46 exercises, which practice the reading skill. Thus, it seems better than the rest distributions of another reading test types, like 1 exercise each (for multiple choice, gap-filling, labeling, and matching), 6 exercises (for fill in the blank), 5 exercises each (for cloze, and reading word aloud), 4 exercises (for the editing task), and 2 exercises each (for responding, short-answer, completing the column) out of 46 exercises. All reading provides essay questions constructed evenly in five chapters of the book besides except reading aloud, editing task, short-answer, fill in the blank and cloze.

\subsection{Higher Order Thinking in Essay Reading: Categories AND Distribution}

54 essay questions were identified from 16 essay reading exercises. Directed from revised Bloom's taxonomy (2001), lower order thinking level (remember, understand, apply) and higher order thinking level (analyze, evaluate, create) were adopted. After examining and categorizing, the higher order thinking activities are found--analyze, evaluation and create. Interestingly, these domains of higher order thinking distributed more than lower order thinking skills. It is proven by the result of the data analysis which shows that the higher order thinking receives $64.8 \%$ while the lower order thinking collects $35.2 \%$. In other word, 1:1.84 comparison.

From 5 chapters, 54 essay reading questions are still lack of higher order thinking level (35 questions) and the rests are lower order thinking (19 questions). there is an unevenness of the numbers of distribution of higher order thinking questions in the essay reading exercise as shown in the following table.

\begin{tabular}{llc}
\hline Higher Order Thinking (HOT) Level & Essay Reading Questions & Percentage \\
\hline Analyze & 12 & $12 / 54 \times 100 \%=22.2 \%$ \\
Evaluate & 19 & $19 / 54 \times 100 \%=35.2 \%$ \\
Create & 4 & $4 / 54 \times 100 \%=7.4 \%$ \\
Total & 35 & $35 / 54 \times 100 \%=64.8 \%$ \\
\hline
\end{tabular}

Table 3. Higher Order Thinking Skilldistribution in essay exercises

The calculation of the ratio between each skill of the higher order thinking looks like, among others: 1:1.6 (between evaluation and analyze), 1:4.8 (between create and evaluation), and 1:3 (betwe en create and analyze). The findings evaluating skill is regarded as the highest level of the taxonomy as Wulandari's studies (2016).

Furthermore, the study demonstrates an unbalanced amount too, inasmuch as, the create domain just obtains $7.4 \%$ only, out of $100 \%$. It is quite startling if compared to the findings in Seif's study that the synthesis skill or create skill acquires a superb number namely $41.35 \%$ (Seif, 2012). It might occur 
because the author assumes that the textbook is addressed for the heterogeneous classes, who are less competent or incapable to answer the questions-based create skill of the higher order thinking skill in much number (Brookhart, 2010). Nevertheless, it is better if the attention of the author of the textbook tends to enrich several essay reading questions into the create skill, particularly in chapter 2 that has none of questions-based in create skill.

First, the analysis skill obtained 12 out of 54 questions or $22.2 \%$. It gets the second place in the distribution of higher order thinking skill. This is available in all five chapters of the tex tbook as well. From 12 questions which belong to the analyze skill, the highest distribution of the questions is from chapter 4, namely, amount to 4 questions. Meanwhile, chapter 1 and chapter 3 have the same distribution, that is, amount to 3 questions each. The same distribution occurs too in chapter 2 and chapter 5 as well, namely 1 question each.

Second one is the evaluate skill. 19 questions out of 54 or $35.2 \%$ belongs to the evaluate skill. It is the highest number among the three skills in the higher order thinking level. Subsequently, the evalu ate skill is also available in all five chapters of the textbook. Further on, the highest distribution of evaluate question is from chapter 2 namely amount to 6 questions out of 19 questions. Whereas, the rest chapters distribute as follow: chapter 1 ( 2 questions), chapter 3 (3 questions), chapter 4 (3 questions), and chapter 5 (5 questions).

The last category is the create skill or the most critical thinking skill. It only distributes 4 questions out of 54 essay reading questions or $7.4 \%$. From 5 chapters of the textbook, there is one chapter of the textbook that does not cover the create level, namely, chapter 2 . In details, those four chapters distribute as follow: chapter 1 (1 question), chapter 3 (1 question), chapter 4 (1 question), and chapter 5 (1 question). However, 4 questions out of 35 higher order thinking questions that belong to the create skill (C6), in fact far away from idea, because the criterion of good questions according to Sudjana (1990) is as follows, $30 \%$ for easy level (C1, C2), $40 \%$ for medium level $(\mathrm{C} 3, \mathrm{C} 4)$, and $30 \%$ for difficult level (C5, C6). That is to say, the create skill (C6) on the basis of good question's criteria should amount of 8 questions while the number questions of other higher order thinking skills are supposed to be as follows, 11 items (analyze), and 8 items (evaluation); so that the percentage of distribution of those higher order thinking skills, in the essay reading exercises in the textbook, are supposed to be as follows, $20.4 \%$ (analyze skill), $14.8 \%$ (evaluate skill), and $14.8 \%$ (create skill). Thus, the proportionate amount of distribution of the higher order thinking skill on the basis of good question's criteria, are supposed to be 27 questions, out of 54 essay reading questions in the textbook.

As addition, this lower create distribution normally occurs through receiveing complex responses (Daiek \& Anter, 2004). This high skill is addressed for higher education settings. This will be a good chance for English teachers to provide their students this skill as a preparation to attend university by distributing the create skill in the essay reading questions. Finally, in the higher order thinking level, the evaluate skill is the focus. Again, it confirms that evaluate skills regardless the two skills. Subsequently, it is still considered as the highest distribution comparing to the other six cognitive domains. Ther e was only 4 out of 54 questions or $7.4 \%$ distribution. The create skill needs to train students to make their original argument, thinking and ideas. In short, varieties of questions are still less paid.

\section{CONCLUSION}

The analyze, evaluate, and create - the three categories of higher order thinking — were available in the essay reading exercises of English textbook entitled Bahasa Inggris SMA/MA XI published by Kemendikbud 2014. This book is fairly promoting critical thinking in English language learning, even though some limitations are also identified. Limitation is found in the contexts of reading assessment and evaluation materials such as authenticity and student empowerment. This is interesting, because critical thinking, higher order thinking, and empowerment is key points in the 21 st century skills. Is sue of authentic reading exercises is still out of discussion. Thus, further analysis in high order thinking should be taken into account.

\section{REFERENCES}

Ary, et al. (2010). Introduction to Research in Education (8th Ed.). Belmont: Wadsworth Cengage Learning.

Brookhart, S. M. (2010). How to Assess Higher-Order Thinking Skills in Your Classroom. Alexandria: ASCD Member Book. 
Daiek, D., \& Anter, N. (2004). Critical Reading for College and Beyond. Boston: The McGraw-Hill Companies.

Farrel, T. S. C. (2002). Planning Lesson for Reading Class. Singapore: SEAMEO Regional Language Center. Retrieved from http://www.relc.org.sg

Igbaria, A. K. (2013). A Content Analysis of the WH-Questions in the EFL Textbook of Horizons. International Education Studies, 6(7).

Krathwohl, D. R. (2002). A Revision of Bloom's Taxonomy: an Overview. -: Taylor and Francis Group and JSTOR.

Lubis, N. (2016). Thinking Order Skills of Reading Comprehension Questions in English Textbook for Eleventh Grade of Senior High School Based on Bloom's Taxonomy. Journal of English Language Teaching of FBS UNIMED, 5(1), 1-12. Retrieved from http://jurnal.unimed.ac.id/2012/index.php/eltu/article/view/5264/4686

Musial, et al. (2009). Foundations of Meaningful Educational Assessment. New York: McGraw-Hill Higher Education.

Sari, I. P. (2017). Reading Exercises for VIII Grade Students Based on Bloom's Taxonomy (Bachelor's thesis, State University of Medan).

Seif, A. A.-Q. (2012). Evaluating the Higher Order Thinking Skills in Reading Exercises of English for Palestine Grade 8. (Doctoral dissertation, The Islamic University-Gaza).

Shen, P., \& Yodkhumlue, B. (2012). A Case Study of Teacher's Questioning and Students' Critical Thinking in College EFL Reading Classroom. International Journal of English Linguistics, 2(1).

Sudjana, N. (1990). Penilaian Hasil Proses Belajar Mengajar. Bandung: PT Remaja Rosdakarya.

Tangsakul, et al. (2017). Using Bloom's Revised Taxonomy to Analyze Reading Comprehension Questions in Team up in English 1-3 and Grade 9 English O-NET Tests. International Journal of Research, 5(7), 31-41. doi: 10.5281/zenodo.826733

Ulum, O. G. (2016). A Descriptive Content Analysis of the Extent of Bloom's Taxonomy in the Reading Comprehension Questions of the Course Book Q: Skills for Success 4 Reading and Writing. The Qualitative Report, 21(9), 1674-1683. Retrieved from http://nsuworks.nova.edu/tqr/vol21/iss9/7

Wulandari, A. I. (2016). A Content Analysis of Reading Comprehension Questions in English Textbook Based on the Revised Version of Bloom's Taxonomy (S-1 thesis, Jember University). Retrieved from http://repository.unej.ac.id/bitstream/handle/123456789/78452/Agustiningsih\%20Ika\%20Wulan dari\%20-\%20120210401087\%20\%20\%23.pdf?sequence=1 
